EUGENIUSZ SAKOWICZ*

Warszawa, Polska

ORCID ID: https://orcid.org/oooo-ooo1-8064-9042
Forum Pedagogiczne $11(2021) 1$

Wpłynęło: 24.02.2021 Zatwierdzono do druku: 7.05.2021 DOI: $10.21697 /$ fp.2021.1.24

\title{
Zbigniew Babicki (2018). Wychowawczo-społeczny wymiar pomocy dzieciom w Rwandzie. Program „Adopcja Serca” - pomiędzy doraźną pomocą a profesjo- nalnym wsparciem. Warszawa: Wydawnictwo Naukowe Uniwersytetu Kardynała Stefana Wyszyńskiego, ss. 466.
}

Tak niedawno, bo zaledwie 27 lat temu świat spoglądał na Afrykę z ogromnym przerażeniem. „Na oczach” współczesnych cywilizowanych społeczeństw, w tym licznych państw chlubiących się z osiągnięć w zakresie demokracji, w Rwandzie miało miejsce ludobójstwo. Bezradność organizacji politycznych o zasięgu międzynarodowym oraz państw spełniających od dziesiątek lat tzw. misje pokojowe w kontekście wojen i bratobójczych walk była zadziwiająca. Nie potrafiono, a może nie chciano już w zarodku zakończyć plemiennych walk w Rwandzie między ludnością Tutsi i Hutu. Genocyd rwandyjski udowodnił, iż afrykański kontent znajduje się daleko „na obrzeżach” świata, a nie w centrum jego zainteresowania. Bieg wydarzeń, w tym również tych dramatycznych, nie ma wpływu na politykę uprawianą na Zachodzie, którym jest nie tylko Europa, lecz także Ameryka. To bardzo dramatyczne spostrzeżenie, którego nie można zignorować, biorąc do ręki wskazaną książkę.

W 2018 roku ukazała się praca autorstwa ks. Zbigniewa Babickiego SAC pt. Wychowawczo-społeczny wymiar pomocy dzieciom w Rwandzie. Program „Adopcja Serca" - pomiędzy doraźna pomoca a profesjonalnym wsparciem. Dziś, po latach od tragedii mieszkańców Rwandy, być może w świadomości czytelnika pojawi się pytanie: Po co temat ten poruszać w Polsce? Czy kogokolwiek z Polaków, poza jednostkami, sytuacja $\mathrm{w}$ tym afrykańskim państwie interesuje? Temat podjęty $\mathrm{w}$ rekomendowanym dziele jest wciąż aktualny $\mathrm{z}$ racji na wyzwania rodzące się w sytuacjach granicznych. Wojna domowa w Rwandzie już się zakończyła. Pochłonęła w ciągu trzech pierwszych miesięcy trwania konfliktu w 1994 roku około miliona ofiar. W latach 1994-1996 w wyniku wojny śmierć poniosło ponad dwa miliony ludzi. A przecież przez dziesięciolecia „wołano” w doświadczonej II wojną światową Europie: „Nigdy więcej wojny!”

Wyżej podane liczby ofiar to nie tylko surowa statystyka, ale nade wszystko znak dramatu setek tysięcy rodzin. Nigdy w Afryce w ciągu krótkiego czasu nie pojawiły się rzesze osieroconych dzieci, tak jak w wyniku wojny domowej w Rwandzie. W kulturze afrykańskiej dziecko, którego rodzice umierają, zawsze znajdzie swój

\footnotetext{
* Prof. dr hab. Eugeniusz Sakowicz, Uniwersytet Kardynała Stefana Wyszyńskiego w Warszawie, Wydział Teologiczny; e-mail: e.sakowicz@uksw.edu.pl.
} 
dom wśród krewnych. Nie przypadkowo bracia i siostry rodziców zawsze byli nazywani - „ojcami” i „matkami”. Cóż począć z dziećmi, które utraciły nie tylko rodziców, lecz także krewnych, pozostając totalnie opuszczonymi? Gdzie mają pójść dzieci, kiedy zginęły ich całe - bliższe i dalsze rodziny, które mogłyby je przygarnąć?

Książka ks. Z. Babickiego SAC powstała nie tylko w oparciu o źródła, literaturę przedmiotu czy inne pisane materiały. Autor odważył się udać do Rwandy w czasie, gdy walki jeszcze trwały. Świadectwem tego są fotografie zamieszczone w książce. Dzieło zrodziło się nie tylko wskutek przemyśleń, lecz i doświadczeń osobistych związanych z - jak mówi pierwsza część tytułu książki z Wychowawczo-społecznym wymiarem pomocy dzieciom $\mathrm{w}$ tym państwie powojennym.

We Wstępie autor pisze: „Ludobójstwo pozostawiło ogrom zniszczeń ekonomiczno-gospodarczych, ale najboleśniejsze i dotąd niezabliźnione rany powstały w sferze egzystencjalnej, psychologicznej i moralnej. W najtrudniejszej sytuacji znalazły się dzieci, okaleczone zarówno cieleśnie, jak i duchowo. Liczbę sierot pozbawionych obojga rodziców szacowano na pół miliona. Utraciły one nie tylko dach nad głową, ale przede wszystkim swój bezpieczny świat, który okazał się bardzo kruchą rzeczywistością. Ekstremalne warunki egzystencjalne, w których znalazły się rwandyjskie dzieci, w sposób drastyczny zahamowały ich wszechstronny rozwój i naraziły na wiele zagrożeń, takich jak bieda, cierpienie, brak poczucia bezpieczeństwa, niekiedy bezpośrednie niebezpieczeństwo utraty zdrowia lub życia, brak miłości i odpowiedniej opieki wychowawczej” (s. 9). Opis ten uzasadnia sens podjęcia przez ks. Z. Babickiego SAC studium, które obecnie prezentujemy, Strukturę pracy wyznaczają następujące części: Wstęp, sześć rozdziałów, Zakończenie, obcojęzyczne streszczenia (w językach: angielskim, francuskim, włoskim) oraz Bibliografia.

Rozdział I - Idea dobra dziecka (s. 19-136) ma charakter wprowadzenia w analizowaną problematykę. W tej części pracy autor zwrócił uwagę na dobro dziecka w ogóle. Wskazał na dzieciństwo jako kategorię społeczno-kulturową. W dalszej kolejności naszkicował perspektywę formalno-prawną idei dobra dziecka, aby ująć dzieciństwo w wymiarze globalnym i lokalnym oraz przedstawić to dobro w perspektywie pedagogiki społecznej. W tym miejscu skupił się na pomocy okazywanej dziecku w jego w rozwoju, a także na opiece społecznej, której jest ono poddane oraz na edukacji środowiskowej. W kolejnych rozważaniach zaprezentował troskę oraz opiekę nad dzieckiem w duchu chrześcijańskim. Przedstawił dzieciństwo zarówno jako zagrożone, jak i zniewolone. Rozdział I zamyka prezentacja założeń tzw. badań własnych oraz informacja o organizacji i przebiegu badań terenowych, prowadzonych przez autora w Rwandzie.

Rozdział II - Rwanda wczoraj i dziś (s. 137-171) omawia rozwój państwowości Rwandy, podaje charakterystykę kraju oraz jego ludności. Przybliża istotne w historii tego państwa okresy: przedkolonialny, kolonialny oraz niepodległości. $\mathrm{Na}$ tle tejże refleksji autor analizuje podłoże konfliktu plemiennego w Rwandzie i relacjonuje w skrócie przebieg ludobójstwa, aby zatrzymać się przy problemie podziału społeczeństwa rwandyjskiego. 
Rozdział III - Społeczna rola Kościoła w Rwandzie (s. 173-205) opisuje powstanie struktur eklezjalnych w tym państwie, nadto znaczenie działalności misyjnej w odbudowie państwa po wojnie plemiennej. Końcowy fragment tej części książki poświęcony jest ewangelizacji w relacji do kultury afrykańskiej.

Rozdział IV - Pallotyni w Rwandzie - w kręgu pedagogii chrześcijańskiej (s. 207283) rozpoczyna się od naszkicowania modelu pedagogii chrześcijańskiej w ogóle. W dalszej części rozdziału przedstawiono pierwszych dziewięć ośrodków palotyńskich w tym państwie. Po przybliżeniu tychże ośrodków misyjnych autor omawia działalność społeczno-religijną misjonarzy. Zwraca uwagę na parafię jako podstawową strukturę tej działalności w środowisku lokalnym. Skupia się na pracy misyjnej na rzecz dziecka i rodziny oraz na pedagogicznym wspomaganiu rodziny. Sygnalizuje wkład pallotynów w rozwój szkolnictwa w tymże państwie. Oryginalną częścią tego rozdziału jest zaprezentowanie pedagogii palotyńskiej wygenerowanej przez rzeczywistość „dziecka i misji”. Autor wskazuje kolejno na składowe pedagogii palotyńskiej: wychowanie religijne, miłość bliźniego, wychowanie do wartości, wychowanie społeczne, animację wychowawczą.

Rozdział V - Adopcja serca" - od wsparcia do samorozwoju (s. 285-322) omawia ideę „Adopcji serca”, jej genezę, powstanie oraz rozwój. U jej podstaw sytuuje się troska o prawidłowy rozwój dziecka, a siłą motywacyjną jest aksjologia, odniesiona do niego i opieki nad nim. Rozdział zamyka refleksja na temat perspektywy rozwoju moralno-religijnego w procesie edukacyjnym.

Rozdział VI - ostatni pt. „Adopcja Serca” - ku profesjonalizacji programu (s. 323369) szkicuje istotę pracy socjalnej oraz ukazuje jej globalny wymiar. Wyróżnia chrześcijańską pracę socjalną, aby na jej tle ukazać specyfikę pallotyńskiego programu misyjnej pracy socjalnej. Autor widzi znaczenie działalności pomocowej opartej na wolontariacie. Rozdział ten zamyka informacja o pracy socjalnej/społecznej prowadzonej w jednostkach organizacyjnych Kościoła oraz o edukacyjnej funkcji misyjnej fundacji „Salvatti”.

Ks. Z. Babicki wskazuje na cel książki: „Zasadniczym zadaniem niniejszej rozprawy - pisze - jest analiza działalności pomocowej na rzecz dzieci w Afryce w ramach programu «Adopcja Serca». Na podstawie oceny realizacji programu zostanie podjęta próba wskazania praktycznego modelu socjalno-wychowawczego odwołującego się do założeń pallotyńskiej pedagogii. Model ten mógłby być narzędziem w rękach pallotyńskich misjonarzy pracujących w Afryce, zwłaszcza w Rwandzie, oraz wszystkich, którzy realizują program wśród dzieci i ich rodzin" (s. 17).

I dodaje: „Niniejsza rozprawa jest pierwszą próbą ukazania pomocowego programu «Adopcja Serca» w świetle teorii i koncepcji pedagogiki społecznej. Jest także próbą wskazania podstaw modelu pallotyńskiej pracy społecznej/socjalnej, który posłużyłby jako wzorzec dla realizacji działań pomocowych na rzecz dzieci w sytuacji ubóstwa. Model ten łączyłby ewangeliczną zasadę miłości, która jest ważnym elementem pedagogii pallotyńskiej, z pragmatycznym i funkcjonalnym 
podejściem do rozwiązywania socjalnych i społecznych problemów jednostek oraz grup społecznych. Można mieć nadzieję, że opracowanie podstaw takiego modelu byłoby ważnym przyczynkiem do profesjonalizacji programu pomocowego «Adopcja Serca», a także wzbogaceniem metod pracy społecznej/socjalnej o wymiar misyjnej działalności Kościoła" (s. 17).

Ks. Z. Babicki SAC omawia program wspierania edukacji dzieci w Rwandzie, kraju doświadczonym ludobójstwem. Książka opisująca działania pomocowe w takich ekstremalnych okolicznościach jednocześnie może być modelowa dla zrozumienia sytuacji $\mathrm{w}$ innych państwach Afryki, nękanych również nienawiścią plemienną. W opisanym przez autora programie "Adopcji Serca” zadania socjalno-opiekuńcze skierowane ku dzieciom zbiegają się z zaspokojeniem ich potrzeb rozwojowo-wychowawczych. W tym właśnie wyraża się oryginalność tego programu, który stanowić może wyzwanie do opracowywania podobnych programów bądź projektów i ostatecznie do podania założeń pracy pomocowej na rzecz dzieci w trudnej sytuacji życiowej. Takie okoliczności są imperatywem do niesienia pomocy, zarówno przez osoby prywatne, instytucje kościelne, organizacje społeczne, jak również różne agendy państwowe.

Troska o dzieci osierocone, realizowana w perspektywie środowiska lokalnego (ale też bardziej globalnie, co nie zawsze jest zauważalne), wyznacza główny kierunek badawczy pedagoga społecznego, którym jest autor rekomendowanej książki. Troska ta znajduje wyraz w dziele pt. Wychowawczo-społeczny wymiar pomocy dzieciom w Rwandzie. Program „Adopcja Serca” - pomiędzy doraźna pomoca a profesjonalnym wsparciem, ważnym dla ekspertów w zakresie edukacji międzykulturowej, specjalistów zaangażowanych w odbudowywanie więzi społecznych oraz edukacji po mrocznych okresach wojen i walk. Książka jest nadto istotna dla afrykanistów, politologów, oraz last but not least - dla misjonarzy, teologów i katechetów, wreszcie - pedagogów. 